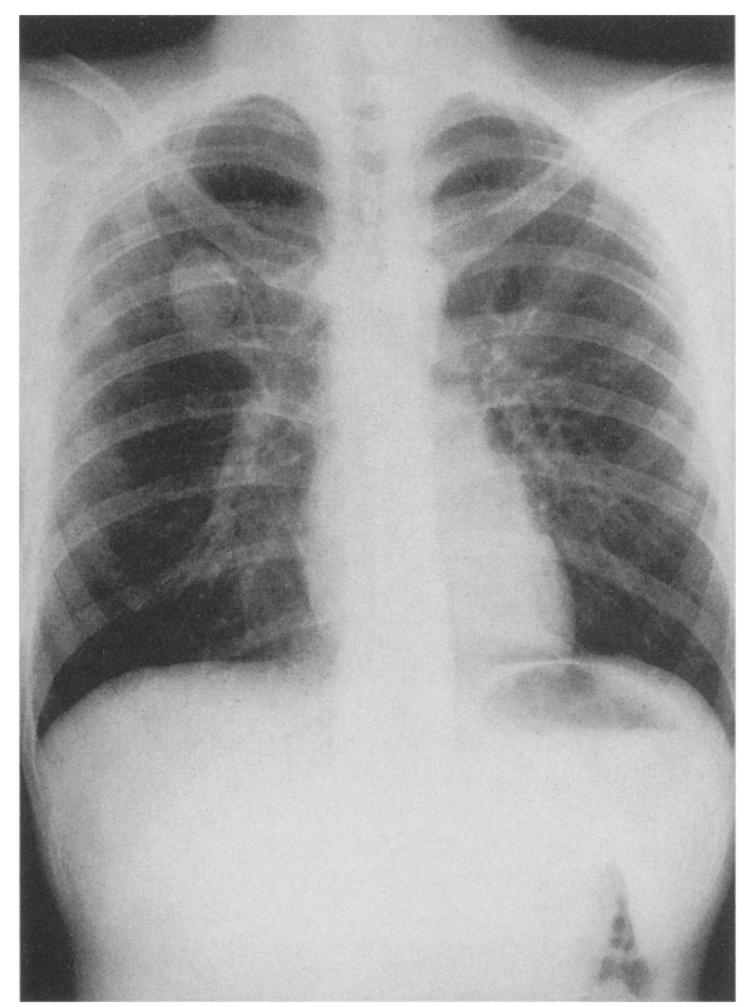

Fig. 2. Roentgenogram of the chest 30 days after repair. A residual hematoma of the right upper lobe and good expansion of the right lower lobe can be seen.

\section{REFERENCES}

1. Baumgartner F, Sheppard B, de Virgilio C, et al. Tracheal and main bronchial disruptions after blunt chest trauma: presentation and management. Ann Thorac Surg 1990:50: 569-74.

2. Mulder DS, Ratnani S. Tracheobronchial trauma. In: Pearson FG, Deslauriers J, Ginsberg RJ, Hiebert CA, McKneally MF, Urschel HC, editors. Thoracic surgery. 1st ed. New York: Churchill Livingstone, 1995:1543-54.

3. Spencer JA, Rogers CE, Westaby S. Clinico-radiological correlates in rupture of the major airways. Clin Radiol 1991:43: 371-6.

4. Hartley C, Morrit GN. Bronchial rupture secondary to blunt chest trauma. Thorax 1993:48:183-4.

5. Symbas PN, Justicz AG, Ricketts RR. Rupture of the airways from blunt trauma: treatment of complex injuries. Ann Thorac Surg 1992:54:177-83.

\title{
HLA ANTIBODIES SPECIFIC FOR CRYOPRESERVED HEART VALVE "HOMOGRAFTS" IN CHILDREN
}

Inez den Hamer, MD, ${ }^{a}$ Bouke Hepkema, PhD, ${ }^{b}$ Jochum Prop, MD, ${ }^{a}$ Nynke Elzenga, MD, ${ }^{\mathrm{c}}$ and Tjark Ebels, MD, ${ }^{\mathrm{a}}$ Groningen, The Netherlands

For more than 30 years, human heart valves have been used as grafts for replacement of diseased aortic and pulmonary valves. These heart valve allografts, tradition-

From the Departments of Cardiopulmonary Surgery, ${ }^{a}$ Transplantation Immunology, ${ }^{b}$ and Pediatric Cardiology, ${ }^{c}$ University Hospital Groningen, Groningen, The Netherlands.

Received for publication March 22, 1996; accepted for publication May 3, 1996.

Address for reprints: Jochum Prop, MD, Cardiopulmonary Surgery, Research Division, University Hospital Groningen, P.O. Box 30.001, 9700 RB Groningen, The Netherlands.

J Thorac Cardiovase Surg 1997;113:417-9

Copyright (C) 1997 by Mosby-Year Book, Inc.

$0022-5223 / 97 \$ 5.00+0 \quad \mathbf{1 2 / 5 4 / 7 4 7 0 8}$ ally referred to as "homografts," were long assumed to be immunologically inert and were supposed not to be affected by rejection, in contrast to organ transplants. However, in children, degeneration of the heart valve allografts is frequently observed. ${ }^{1}$ Findings in clinical ${ }^{2,3}$ and experimenta $\left.\right|^{4}$ studies suggested that this degeneration might be caused by an immune response. Recently, Smith and colleagues ${ }^{5}$ from the Harefield Hospital, United Kingdom, found donor HLA-specific antibodies in adults after implantation of fresh or antibiotic-sterilized aortic valve allografts. This demonstrated that human heart valve allografts can induce immune responses in patients.

Most cardiac centers do not have fresh heart valve allografts available and use cryopreserved valves instead, which have been shown to become less immunogenic during the cryopreservation procedure. ${ }^{3}$ Therefore we investigated whether cryopreserved heart valve allografts induced donor-specific HLA antibodies in children. 
Table I. Specificity and isotype of HLA antibodies in eight children with cryopreserved heart valve allografts

\begin{tabular}{|c|c|c|c|c|c|c|}
\hline Serum sample* & Aget & Diagnosis & $\begin{array}{c}\text { Type of valve } \\
\text { allograft }\end{array}$ & $\begin{array}{c}H L A \text { antigens of } \\
\text { valve donor }\end{array}$ & $\begin{array}{l}\text { HLA antibodies } \\
\text { and isotype }\end{array}$ & $\begin{array}{c}\text { Red blood } \\
\text { cellst }\end{array}$ \\
\hline $2 \mathrm{Wk}$ & 1 & Pulmonary valve atresia & Pulmonary & Not determined & $\mathrm{B} 17 ; \operatorname{Ig} \mathrm{M}$ & 4 \\
\hline $5 \mathrm{Mo}$ & 1 & Pulmonary valve atresia & Aortic & $\mathrm{A} 1, \mathrm{~A} 2, \mathrm{~B} 18, \mathrm{~B} 37$ & $\mathrm{~A} 1 ; \mathrm{IgG}$ & 11 \\
\hline $1 \mathrm{Yr}$ & 11 & Tetralogy of Fallot & Aortic & Not determined & No & 3 \\
\hline $3 \mathrm{Yr}$ & 0 & Truncus arteriosus & Aortic & First: A1, A2, B37, B39 & No & 0 \\
\hline $3.5 \mathrm{Yr} \&$ & & & & Second: A2, A24, B18, B35 & & \\
\hline $4 \mathrm{Yr}$ & 17 & Pulmonary valve stenosis & Pulmonary & $\mathrm{A} 24, \mathrm{~A} 32(\mathrm{~A} 19), \mathrm{B} 44, \mathrm{~B} 61$ & $\mathrm{~A} 10, \mathrm{~A} 19 ; \mathrm{IgG}$ & 14 \\
\hline $4.5 \mathrm{Yr}$ & 4 & Pulmonary valve insufficiency & Aortic & Not determined & No & 5 \\
\hline $5 \mathrm{Yr}$ & 1 & Tetralogy of Fallot & Aortic & $\mathrm{A} 24, \mathrm{~B} 51(\mathrm{~B} 5), \mathrm{B} 49$ & B5, B49; IgG & 8 \\
\hline $5 \mathrm{Yr}$ & 6 & Aortic valve stenosis & Aortic & First: A1, A24, B8, B39 & No & 3 \\
\hline $6 \mathrm{Yr} \S$ & & & & Second: Not determined & & \\
\hline
\end{tabular}

*Time after operation.

†Age in years at time of operation.

$\ddagger$ Units of unfiltered red blood cell concentrates received perioperatively.

§Patient underwent operation twice.

Table II. Specificity of HLA antibodies in one patient and HLA antigens of heart valve donor and blood donors

\begin{tabular}{ll}
\hline \multicolumn{2}{c}{ HLA specificitylantigens } \\
\hline HLA antibodies & $\mathrm{B} 5, \mathrm{~B} 49$ \\
Valve donor & $\mathrm{A} 24, \mathrm{~B} 51(\mathrm{~B} 5), \mathrm{B} 49$ \\
Blood donor 1 & $\mathrm{A} 2, \mathrm{~B} 7, \mathrm{~B} 62$ \\
Blood donor 2 & $\mathrm{A} 2, \mathrm{~A} 3, \mathrm{~B} 7$ \\
Blood donor 3 & $\mathrm{A} 29, \mathrm{~A} 32, \mathrm{~B} 44$ \\
Blood donor 4 & $\mathrm{A} 1, \mathrm{~A} 2, \mathrm{~B} 62, \mathrm{~B} 37$ \\
Blood donor 5 & $\mathrm{A} 2, \mathrm{~A} 30 / \mathrm{A} 31, \mathrm{~B} 44, \mathrm{~B} 27$ \\
Blood donor 6 & $\mathrm{A} 1, \mathrm{~A} 24, \mathrm{~B} 7, \mathrm{~B} 8$ \\
Blood donor 7 & $\mathrm{A} 3, \mathrm{~A} 30 / 31, \mathrm{~B} 13, \mathrm{~B} 35$ \\
Blood donor 8 & Not determined \\
\hline
\end{tabular}

Eight children who underwent operation for congenital heart defects (Table I) were studied between 2 weeks and 5 years after implantation of a cryopreserved heart valve allograft. The age of the children at the time of operation ranged from 1 month to 17 years; two of the children had undergone operation twice; all but one of the children received unfiltered red blood cell concentrates (Table I). In a study protocol approved by the Medical Ethical Committee of our institution, the patients (and parents) allowed collection of a single blood sample for analysis of HLA antibodies; no permission was obtained for HLA typing in these patients.

For the detection of cytotoxic anti-HLA class I antibodies and for the crossmatches, the standard National Institutes of Health microlymphocytotoxicity technique and a more sensitive assay that used longer incubation times were used. The sera were screened against peripheral blood lymphocytes of a panel of 40 different HLA-typed healthy volunteers. Pretreatment of the sera with dithiothreitol was used to differentiate between immunoglobulin $(\mathrm{Ig}) \mathrm{G}$ and $\operatorname{IgM}$ antibodies.

Cytotoxic HLA antibodies were detected in the serum of four of the eight children. In three children HLA antibodies of the $\operatorname{IgG}$ isotype were directed specifically against HLA antigens of the allograft donor; the donor specificity of the IgM HLA antibodies detected in the fourth patient could not be confirmed because the donor HLA typing was not available.

In one patient, with HLA antibodies specific for the relatively rare HLA-B5 and -B49 antigens, analysis was done in detail, to exclude the possibility that the HLA antibodies were induced by blood transfusions. All but one of the blood donors were retrospectively typed for HLA antigens. None of the blood donors had the B5 or B49 antigens (Table II) and the crossmatches between the serum of the patient and lymphocytes of the blood donors were all negative. One blood donor was not available for HLA typing but it is unlikely that this single donor had HLA antigens corresponding with the specificities of the HLA antibodies.

This report demonstrates that in children cryopreserved heart valve allografts can induce donor-specific, cytotoxic HLA antibody responses. Children have high humoral anti-HLA responsiveness, ${ }^{6}$ and they also frequently show degeneration of implanted heart valve allograft. ${ }^{1}$ If we accept the concept that this degeneration is immune mediated, the obvious consequence for clinical treatment of the children would be to prevent the immune response against the heart valve allograft. One way to achieve this could be treatment of patients with immunosuppressive drugs as was shown effective in rats. ${ }^{7}$ For children this treatment is not appealing, because of the side effects of immunosuppression.

Another way to prevent immune responses against valve allografts is prospective selection of an HLAmatched valve for each patient. Ideally the allografts should be matched for both HLA class I and II antigens. Class I matching has been shown to reduce rejection in high-risk corneal transplantation ${ }^{8}$ and class II matching reduced in vitro the stimulation of lymphocytes by heart valve tissue. ${ }^{3}$ The major obstacle to achieving adequate HLA matching of heart valve allografts, next to size matching, is that it would restrict the availability of suitable valve allografts for individual patients. In addition, the effect of prospective matching would only be of 
benefit for patients with an increased risk for degeneration of the valves. At present it is impossible to assess prospectively which patients are at risk for immunemediated valve degeneration. However, children listed for retransplantation for reasons other than technical failure and children with preformed HLA antibodies are likely candidates. We recommend that for these patients at "high risk" a crossmatch-negative, HLA-matched heart valve allograft be selected.

The cooperation of the Stichting Rode Kruis Bloedbank Noord Nederland, their blood donors, and Bio Implant Services for providing the HLA types of the donors is gratefully acknowledged.

\section{REFERENCES}

1. Clarke DR, Campbell DN, Hayward AR, Bishop DA. Degeneration of aortic valve allografts in young recipients. J Thorac Cardiovasc Surg 1993;105:934-42.

2. Yankah AC, Wottge HU, Muller-Hermelink HK, et al. Transplantation of aortic and pulmonary allografts, enhanced via- bility of endothelial cells by cryopreservation, importance of histocompatibility. J Card Surg 1987;2(suppl):209-20.

3. Hoekstra F, Knoop C, Jutte N, et al. Effect of cryopreservation and HLA-DR matching on the cellular immunogenicity of human cardiac valve allografts. J Heart Lung Transplant 1994:13:1095-8.

4. Zhao XM, Green M, Frazer IH, Hogan P, O'Brien MF. Donor-specific immune response after aortic valve allografting in the rat. Ann Thorac Surg 1994;57:1158-63.

5. Smith JD, Ogino H, Hunt D, Laylor RM, Rose ML, Yacoub MH. Humoral immune response to human aortic valve homografts. Ann Thorac Surg 1995;60:S127-30.

6. Scornic JC, Pfaff WW, Howard RJ, et al. Increased antibody responsiveness to blood transfusions in pediatric patients. Transplantation 1994;58:1361-5.

7. Yankah AC, Wottge HU, Muller-Ruchoitz W. Short-course cyclosporin a therapy for definite allograft valve survival immunosuppression in allograft valve operations. Ann Thorac Surg 1995;60:146-50.

8. Sanfilippo F, MacQueen JM, Vaughn WK, Foulks GN. Reduced graft rejection with good HLA-A and B matching in high-risk corneal transplantation. N Engl J Med 1986;315:29-35.

\section{MULTIPLE EPISODES OF THROMBOSIS WITH BIVENTRICULAR SUPPORT DEVICES WITH INADEQUATE ANTICOAGULATION AND EVIDENCE OF ACCELERATED INTRAVASCULAR COAGULATION}

George J. Despotis, MD, Vladimir Levine, MD, PhD, Heinrich Joist, MD, PhD, Samuel A. Santoro, MD, PhD, and Eric Mendeloff, MD, St. Louis, Mo.

Ventricular assist devices (VADs) may induce complex hemostatic abnormalities mediated by excessive activation of platelets, coagulation, and fibrinolysis with resulting consumption of platelets and labile coagulation factors and sometimes associated with thrombosis. ${ }^{1-3}$ We describe the case of a teenaged boy with

From the Departments of Anesthesiology, Internal Medicine, Pathology, and Surgery, Washington University School of Medicine, and the Departments of Internal Medicine and Pathology, St. Louis University School of Medicine, St. Louis, Mo.

Supported in part by a research grant from ABIOMED, INC.

Received for publication August 9, 1996; accepted for publication Sept. 12, 1996.

Address for reprints: George Despotis, MD, Division of Cardiothoracic Anesthesiology, Department of Anesthesiology, Box 8054, Washington University School of Medicine, 660 South Euclid Ave., St. Louis, MO 63110.

J Thorac Cardiovasc Surg 1997;113:419-22

Copyright $(\mathcal{C} 1997$ by Mosby-Year Book, Inc.

$0022-5223 / 97 \$ 5.00+0 \quad \mathbf{1 2 / 5 4 / 7 8 0 3 1}$ dilated cardiomyopathy whose course was initially complicated by excessive bleeding. He subsequently had multiple episodes of thrombosis of biventricular assist devices (BVADs) that were associated with accelerated intravascular coagulation temporally related to suboptimal warfarin anticoagulation.

A 15-year-old boy with Becker's muscular dystrophy was admitted for treatment of progressive congestive heart failure. Transthoracic echocardiography revealed dilated cardiomyopathy with severely reduced ejection fraction and a right ventricular mural thrombus. Over a 3-week period after admission, he began having increasingly severe symptoms of congestive heart failure with respiratory distress and profound hypotension. The symptoms were unresponsive to aggressive medical management with inotropic support, diuresis, afterload reduction, and intraaortic balloon counterpulsation. After the development of cardiogenic shock, ABIOMED BVADs (ABIOMED Cardiovascular, Inc., Danvers, Mass.) were implanted as a bridge to transplantation (day 1). The patient was given a continuous infusion of heparin at a rate of 1500 to $2200 \mathrm{U} / \mathrm{hr}$ to maintain the celite activated clotting time between 180 and 200 seconds. While he was 